\title{
NAC-1, a Rat Brain mRNA, Is Increased in the Nucleus Accumbens Three Weeks after Chronic Cocaine Self-Administration
}

\author{
Xian-Yuan Cha, ${ }^{1}$ R. Christopher Pierce, ${ }^{2}$ Peter W. Kalivas, ${ }^{2}$ and Scott A. Mackler ${ }^{1}$ \\ ${ }^{1}$ Department of Medicine, Philadelphia Veterans Administration Medical Center and University of Pennsylvania School of \\ Medicine, Philadelphia, Pennsylvania 19104, and ${ }^{2}$ Alcohol and Drug Abuse Program, Washington State University, \\ Pullman, Washington 99164-6520
}

\begin{abstract}
Chronic cocaine use leads to biochemical and behavioral changes that can persist for weeks to months after drug administration is discontinued. Alterations in gene expression in the mammalian CNS may contribute to these long-term neural consequences of cocaine abuse. A combined in situ transcription-PCR amplification strategy was used to isolate a novel mRNA, NAC-1, from the nucleus accumbens of rats 3 weeks after discontinuing 3 weeks of intravenous cocaine self-administration. In rats that selfadministered cocaine, levels of NAC- 1 were increased $\sim 50 \%$ in the nucleus accumbens but not in the dorsal striatum or hippocampus, when compared with levels from yoked-saline controls. In situ hybridization analysis demonstrated increased numbers of NAC-1-expressing cells in the nucleus accumbens of rats who had self-administered cocaine. NAC-1 mRNA exists as one
\end{abstract}

form, $\sim 4400$ nucleotides (nt) in size, and also is present at much lower amounts in non-neural tissues. A full-length cDNA clone was isolated from a whole brain library. The predicted polypeptide sequence contains a POZ domain in the first 120 amino acids; the same POZ domain sequence mediates protein-protein interactions among some transcriptional regulators. NAC-1 mRNA levels were also increased in the nucleus accumbens 1 week after $6 \mathrm{~d}$ of noncontingent cocaine treatments. Regulation of NAC-1 mRNA in the nucleus accumbens demonstrates a long-term effect of cocaine use on cellular function that may be relevant in behavioral sensitization or cocaine self-administration.

Key words: cocaine; self-administration; behavioral sensitization; mRNA; POZ domain; nucleus accumbens
Repeated cocaine use in rats is associated with long-term changes in behavior, including behavioral sensitization and stable patterns of cocaine self-administration. Behavioral sensitization is manifest as an augmented locomotor response in response to a single cocaine injection and is present many weeks after repeated and intermittent cocaine treatments (Robinson and Becker, 1986; Kalivas and Stewart, 1991). The nucleus accumbens is one brain nucleus in which long-term changes in neuronal function result from repeated cocaine administration (Kalivas and Stewart, 1991; Nestler, 1992; F. J. White et al., 1995). For example, enhanced pre- and postsynaptic dopamine transmissions are associated with the expression of behavioral sensitization to both noncontingentand self-administered cocaine (Kalivas and Duffy, 1993; Hooks et al., 1994; S. R. White et al., 1995; Heidebreder et al., 1996). The self-administration of cocaine is disrupted by dopamine depletion or inactivation of G-proteins in the nucleus accumbens, further emphasizing the importance of this region in cocaine-associated behaviors (Roberts et al., 1977; Pettit et al., 1984; Self et al., 1994).

Regulation of neuronal gene expression is hypothesized to be one mechanism by which cocaine leads to persistent behavioral changes (Mackler and Eberwine, 1992; Nestler, 1992). Several mRNAs demonstrate increased or decreased levels in the CNS in

Received March 6, 1997; revised June 9, 1997; accepted June 27, 1997.

This work was supported by National Institute on Drug Abuse Grants DA-00199, DA-03906, MH-40817, and DA-05589. We thank Kevin Miyashiro (for use of the rat RNA blot), Thomas R. Kleyman (for helpful discussions), and the Philadelphia VAMC Medical Media (for preparation of figures).

Correspondence should be addressed to Dr. Scott A. Mackler, Medical Research Service (151C), Philadelphia Veterans Administration Medical Center, Philadelphia, PA 19104

Copyright (C) 1997 Society for Neuroscience $0270-6474 / 97 / 176864-08 \$ 05.00 / 0$ response to cocaine injections; these mRNAs include those for multiple transcriptional activators, neuropeptides, and other molecules (Graybiel et al., 1990; Hope et al., 1992; Hurd et al., 1992; Nestler, 1992; Bhat and Baraban, 1993; Daunais and McGinty, 1995; Douglass et al., 1995). Previous studies have examined mRNA levels either after single or multiple injections in a noncontingent paradigm or in the early stages of withdrawal after passive cocaine administration. The present study was designed to study specific mRNAs in the nucleus accumbens of rats several weeks after a 3 week period of intravenous cocaine selfadministration to identify persistent changes in gene expression associated with cessation of cocaine use. mRNAs encoding multiple somatostatin receptor subtypes (SSTRs) (Raynor et al., 1993a) were initially selected for examination, because injection of somatostatin analogs into the anterior nucleus accumbens of adult male rats increases locomotor activity when compared with saline injections (Raynor et al., 1993b) in a manner similar to acute cocaine administration (Delfs et al., 1990). This report describes how PCR amplification using oligonucleotides for the $\mathrm{SSTR}_{4}$ receptor subtype resulted in identification of a novel mRNA, named NAC-1 because of its isolation from the nucleus accumbens, that was present at increased levels in the nucleus accumbens 3 weeks after cocaine self-administration.

\section{MATERIALS AND METHODS}

Self-administration of cocaine and collection of brain sections. Male Sprague Dawley rats weighing 300-350 gm (Simonsen Laboratories, Gilroy, CA) were individually housed with food and water available $a d$ libitum. Self-administration was performed during the light cycle (12/12 hr light/dark cycle with lights turned on at 7:00 A.M.). Rats were anesthetized with Equithesin $(3.0 \mathrm{ml} / \mathrm{kg}$, i.p.), and intravenous catheters were implanted and sutured into the external jugular vein. Each catheter was routed to a screw-on mount (Plastics One, Roanoke, 
VA) that was glued and sutured in place on the animal's back. After a $5 \mathrm{~d}$ recovery period from surgery, the rats were placed individually in a self-administration apparatus (Med Associates, East Fairfield, VT) and allowed to press a lever for cocaine $\mathrm{HCl}$ on a fixed ratio one schedule of reinforcement ( $3 \mathrm{hr} / \mathrm{d}, 6 \mathrm{~d} /$ week). Each self-administration cage contained one active and one inactive lever. The catheters were flushed with $0.15 \mathrm{ml}$ of heparin (10 USP U/ml; Abbott Labs, North Chicago, IL) before and after a self-administration session. Two priming injections signaled the beginning of each self-administration session. During the training phase the rats acquired the selfadministration behavior via autoshaping; each press of the active lever delivered $0.33 \mathrm{mg}$ of cocaine in $0.05 \mathrm{ml}$ of $0.9 \%$ sterile saline over $3 \mathrm{sec}$. A cue light over the active lever was illuminated at the initiation of each inf usion, and the lever was deactivated for $20 \mathrm{sec}$. When responding for cocaine stabilized, the rats were allowed access to cocaine over 18 daily $3 \mathrm{hr}$ sessions (with a day off after every sixth consecutive day of cocaine self-administration). Each rat trained to self-administer cocaine was paired with a control animal yoked to receive an identical volume of saline with each injection of cocaine by the experimental rat. The rats were removed from the $18 \mathrm{~d}$ of daily cocaine access for a $21 \mathrm{~d}$ period. At the end of this time the rats were decapitated, and the brains were rapidly removed and frozen in powdered dry ice.

Noncontingent cocaine treatment. Three different groups of adult male Sprague Dawley rats received injections of cocaine to determine the time course of NAC-1 expression in the nucleus accumbens. (1) Acute cocaine: these rats received one $15 \mathrm{mg} / \mathrm{kg}$ intraperitoneal injection of cocaine and were killed 1 or $24 \mathrm{hr}$ after the injection. (2) Chronic cocaine: these rats received daily $30 \mathrm{mg} / \mathrm{kg}$ intraperitoneal cocaine injections for $6 \mathrm{~d}$ and were killed $6 \mathrm{hr}$ after the last injection. (3) One week withdrawal: these rats also received $6 \mathrm{~d}$ of daily $30 \mathrm{mg} / \mathrm{kg}$ intraperitoneal cocaine injections and were then killed 1 week later. The same investigators injected the rats daily at the same time during the dark cycle. Control animals received identical volumes of intraperitoneal saline injections. Each group had a minimum of four cocaine- and four saline-treated rats.

In situ transcription and PCR amplification. Coronal sections $(\sim 14$ $\mu \mathrm{m}$ thick) were cut at $-20^{\circ} \mathrm{C}$ from the forebrain to the pons, fixed in $4 \%$ paraformaldehyde/PBS, $\mathrm{pH} 7.4$, for $5 \mathrm{~min}$, and frozen at $-80^{\circ} \mathrm{C}$ until later use. In situ transcription was performed as described previously (Tecott et al., 1988; Mackler and Eberwine, 1995). An oligonucleotide (consisting of the T7 bacteriophage RNA polymerase promoter sequence positioned $5^{\prime}$ to 24 thymidine residues) was used to prime cDNA synthesis in each tissue section. In situ transcription proceeded at $41^{\circ} \mathrm{C}$ for 90 min [final conditions: $120 \mathrm{~mm} \mathrm{KCl} ; 5 \mathrm{~mm}$ $\mathrm{MgCl}_{2} ; 50 \mathrm{~mm}$ Tris-HCl, $\mathrm{pH} 8.3 ; 250 \mu \mathrm{M}$ each dNTP; $0.5 \mathrm{U} / \mu \mathrm{l}$ RNAsin; and $2 \mathrm{U} / \mu \mathrm{l}$ AMV reverse transcriptase (Seikagaku America, Rockville, MD)]. One tissue section in each group included $25 \mu \mathrm{Ci}$ of $\left[\alpha{ }^{3}{ }^{32} \mathrm{P}\right] \mathrm{dCTP}$ in the reaction mix; incorporation of the radioisotope was used to demonstrate successful cDNA synthesis. All tissue surrounding the nucleus accumbens was removed with a scalpel after in situ transcription. The first-strand cDNA transcripts from three sections of the nucleus accumbens of the rat were isolated by alkaline denaturation and pooled together (Mackler and Eberwine, 1995). One percent of each cDNA sample was used in an amplification reaction [final conditions: $1 \times$ buffer $(50 \mathrm{~mm}$ Tris- $\mathrm{HCl}$ and $50 \mathrm{~mm} \mathrm{KCl}), 2.0 \mathrm{~mm}$ $\mathrm{MgCl}_{2}, 200 \mathrm{ng}$ of each primer, $250 \mu \mathrm{M}$ each dNTP, and $2.5 \mathrm{U}$ of Taq DNA polymerase (Perkin-Elmer Cetus, Emeryville, CA)]. The primers used were denoted $\mathrm{SSTR}_{4}$ (bp 739-758 for the sense strand of the SSTR subtype 4 cDNA, 5'-ATCGCAGTCTTCGCTGACAC-3') and TM7 (bp 1125-1106 for the complementary strand of the $\mathrm{SSTR}_{4}$ cDNA, 5'-GGGTTGGCACAGCTATTGGC-3'). PCR conditions were $95^{\circ} \mathrm{C}$ for $5 \mathrm{~min} ; 35 \mathrm{cycles}$ of $95^{\circ} \mathrm{C}$ for $60 \mathrm{sec}, 58^{\circ} \mathrm{C}$ for $90 \mathrm{sec}$, and $72^{\circ} \mathrm{C}$ for $90 \mathrm{sec}$; and $72^{\circ} \mathrm{C}$ for $5 \mathrm{~min}$. One-fifth of each reaction was examined by electrophoresis in a $1.5 \%$ agarose gel. PCR products were isolated after separation in a $1.5 \%$ agarose gel and were subcloned into the vector pCR II (Invitrogen, San Diego, CA).

Northern blot analysis. Brains from other cocaine-injecting and yokedsaline rats were mounted in the cryostat, and tissues from the nucleus accumbens, dorsal striatum (caudate-putamen), hippocampus, and other regions were dissected from the block with a scalpel. Polyadenylated $\left[\operatorname{poly}\left(\mathrm{A}^{+}\right)\right]$RNA was isolated from these regions of individual rats (MicroFast Track RNA; Invitrogen, San Diego, CA) and separated in a $1.2 \%$ agarose $/ 2.5 \mathrm{M}$ formaldehyde gel. These poly $\left(\mathrm{A}^{+}\right)$blots were probed with the initial $207 \mathrm{bp}$ cDNA insert obtained from PCR amplification with the primers $\mathrm{SSTR}_{4}$ and TM7 and with the insert cDNA for IB15 (cyclophilin). Probes were labeled to a specific activity of $>2 \times 10^{8}$ $\mathrm{cpm} / \mu \mathrm{g}$ cDNA (Feinberg and Vogelstein, 1983). Final posthybridization washes were in $0.1 \times \mathrm{SSC}$ at $60^{\circ} \mathrm{C}$. Images were obtained using both a PhosphorImager (Molecular Dynamics, Sunnyvale, CA) and XAR film autoradiography. Values for NAC-1 were calculated as a percentage of the signal for cyclophilin (selected as a constitutively expressed mRNA). The percentages for CNS samples from cocaine-injecting rats were normalized to the percentages for samples from saline-treated rats within the same blot, and comparisons were made between cocaine and saline groups using a Student's two-tailed $t$ test. Another denaturing gel contained total RNA at $20 \mu \mathrm{g} /$ lane from different tissues of drug-naive adult male Sprague Dawley rats and was probed with a $2064 \mathrm{bp}$ cDNA that contained the entire open reading frame of NAC-1. This RNA gel was used to determine the regional tissue distribution of NAC-1.

Isolation of a full-length cDNA clone. The initial PCR cDNA product (207 bp in length) was random prime-labeled (as above) and used to screen $\sim 7.5 \times 10^{5}$ plaques of a rat whole brain library (Stratagene, La Jolla, CA; 6-week-old male rat). The final washes of this screen were in $0.1 \times \mathrm{SSC}$ at $60^{\circ} \mathrm{C}$. Eleven separate plaques were isolated after secondary and tertiary screens, and the insert cDNAs were removed by in vivo excision into pBluescript II SK (Short et al., 1988). The identities of each clone were determined by chain termination DNA sequencing (Sanger et al., 1977). Ten of the 11 clones were entirely part of NAC-1, based on identical regions of overlapping sequences. The one remaining clone demonstrated $90 \%$ sequence similarity with NAC-1. The DNA and amino acid sequences were compared with other known cDNAs and proteins (Altschul et al., 1990).

In situ hybridization analysis. Riboprobe was synthesized with the addition of digoxigenin-UTP (Muhlegger et al., 1989). Tissue sections adjacent to those used in in situ transcription were pretreated with proteinase $\mathrm{K}$ followed by hybridization mix $(50 \%$ formamide, $5 \times \mathrm{SSC}$, $250 \mu \mathrm{g} / \mathrm{ml}$ tRNA, $175 \mu \mathrm{g} / \mathrm{ml}$ salmon sperm DNA, and 1\% SDS), and then either antisense or sense cRNA at $2 \mu \mathrm{g} / \mathrm{ml}$ was added to the hybridization mix and allowed to hybridize overnight at $55^{\circ} \mathrm{C}$. Posthybridization steps included an RNase A treatment and a final wash in $0.1 \times$ SSC at $60^{\circ} \mathrm{C}$. The digoxigenin-labeled cRNAs were detected by use of 4-nitroblue tetrazolium chloride and 5-bromo-4-chloro-3-indolylphosphate after the addition of an anti-digoxigenin antibody conjugated to alkaline phosphatase (all reagents from Boehringer Mannheim, Indianapolis, IN). Stained cells within a $2.5 \mathrm{~mm} \times 1.25 \mathrm{~mm}$ rectangular grid centered over the anterior portion of the anterior commissure (location $\sim 1.20 \mathrm{~mm}$ from the bregma) were counted (two rats per group).

\section{RESULTS}

\section{Self-administration of cocaine}

The experimental rats $(n=7)$ self-administered cocaine $28.9 \pm$ 4.2 times per daily $3 \mathrm{hr}$ session, averaged over the 18 selfadministration sessions. This corresponds to a mean of $27.2 \pm 3.8$ $\mathrm{mg} / \mathrm{kg}$ cocaine injected by each rat per day.

\section{PCR amplification of a novel cDNA and long-term regulation after cocaine use}

cDNAs obtained from in situ transcription of coronal sections containing the nucleus accumbens were used as templates for PCR amplification. The sizes of the population of cDNAs obtained from in situ transcription using nucleus accumbens tissue ranged from $\sim 250$ to $3000 \mathrm{bp}$ in length (data not shown). PCR amplification using the oligonucleotides $\mathrm{SSTR}_{4}$ and TM7 as primers resulted in a cDNA product of the predicted size for $\operatorname{SSTR}_{4}(\sim 380 \mathrm{bp})$ and a smaller cDNA ( 200 bp). The $\operatorname{SSTR}_{4}$ cDNA ( $\sim 380$ bp) was present in the nucleus accumbens samples from all cocaine- and saline-treated rats. The smaller cDNA ( $\sim 200 \mathrm{bp})$ was detected in the nucleus accumbens samples from each cocaine-injecting rat $(n=5)$ but was present in only one-half of the nucleus accumbens cDNAs from yoked-saline control animals $(n=6)$. The nucleic acid sequence of this smaller cDNA was established after subcloning, and this insert cDNA was used to probe several regions of individual rat brains of both the cocaine and yoked-saline treatment groups (Fig. 1). A single mRNA species was detected in each examined brain region (the data from nucleus accumbens, hip- 
Nucleus Accumbens

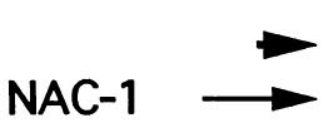

IB1 5
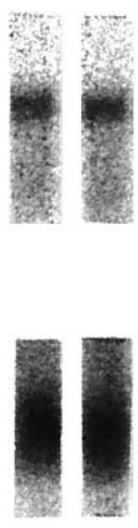

C S
Hippocampus
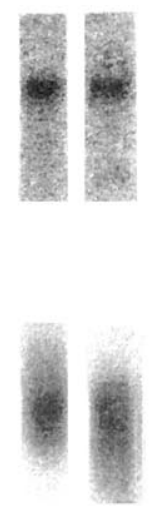

C S

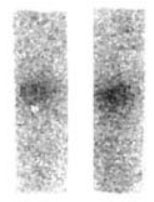

Caudate-Putamen

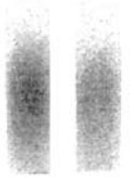

C S

Figure 1. NAC-1 mRNA is detected in multiple CNS regions. Northern blots were performed using poly(A $\left.{ }^{+}\right)$RNA isolated from discrete CNS regions of individual rats. Partial-length cDNAs for $N A C-1$ and cyclophilin (IB15) were used as probes. Digitized images are shown after $4 \mathrm{~d}(N A C-1)$ or 8 hr (IB15) phosphorscreen exposures. These representative Northern blots demonstrate that NAC-1 mRNA occurs as a single size, $\sim 4400$ nt. The amount of NAC-1 mRNA relative to cyclophilin mRNA was greater in nucleus accumbens samples from rats that had self-administered cocaine $(C)$ than from yoked-saline controls $(S)$. The relative amounts of NAC-1 mRNA did not differ between the two treatment groups in the hippocampus and the caudate-putamen. The arrowhead indicates the position of $28 \mathrm{~S}$ rRNA.

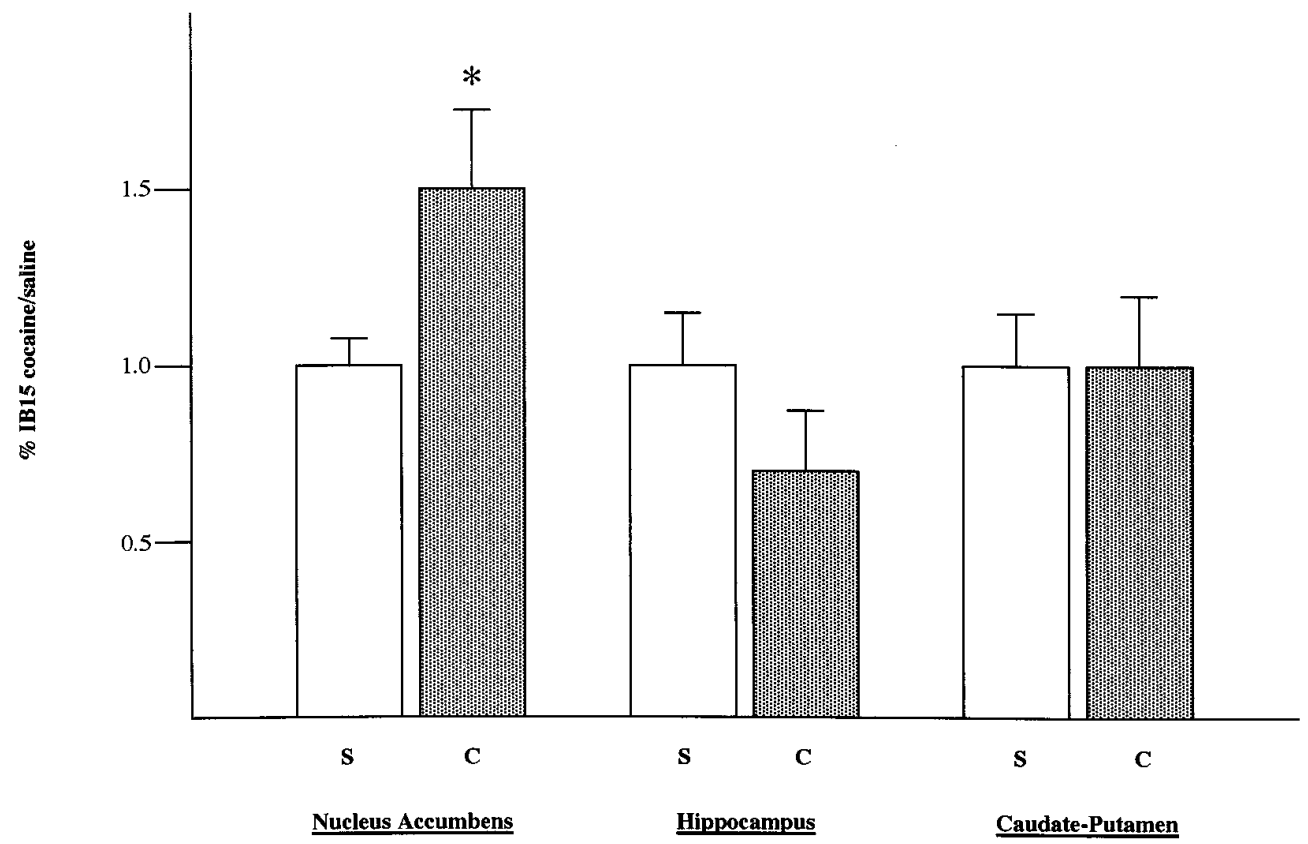

Figure 2. NAC-1 mRNA is present at increased levels in the nucleus accumbens after withdrawal from cocaine self-administration. The levels of NAC-1 mRNA as a percentage of cyclophilin mRNA are shown as values normalized to the values from saline-exposed rats. Cyclophilin mRNA, a constitutively expressed gene, was used as a measure of RNA transfer in each blot. The level of NAC-1 mRNA in the nucleus accumbens of cocaine-exposed rats $(C)$ is $\sim 50 \%$ higher when compared with that of saline-treated rats $(S)$. No significant changes were observed in levels of NAC-1 mRNA in the hippocampus or caudate-putamen. A minimum of four rats was used for each group ( ${ }^{*} p<0.05$; Student's $t$ test).

pocampus, and caudate-putamen are shown in Fig. 1). Figure 2 demonstrates that the relative amount of mRNA for NAC-1 was $\sim 50 \%$ greater in the nucleus accumbens of cocaine-injecting rats compared with yoked-saline controls after a 3 week withdrawal period. Figure 2 also shows that no differences were observed between cocaine-exposed and control rats using poly $\left(\mathrm{A}^{+}\right) \mathrm{RNA}$ from the hippocampus and caudate-putamen. In addition, a smaller number of samples ( $n=2$ /group) revealed no apparent differences between treatments in the amount of NAC-1 mRNA in the ventral tegmental area or hypothalamus (data not shown).

\section{Identification of a putative full-length clone for NAC-1}

Eleven plaques were isolated after a high-stringency screen of a rat whole brain library. One cDNA clone, 2042 bp in length, 
contains an open reading frame encoding a protein of 514 amino acids. The nucleic acid and amino acid sequences are shown in Figure 3 . The total length of the 10 other cDNA clones, accounting for overlapping regions of identical sequences, is $\sim 4400 \mathrm{bp}$. No other open reading frames encoding a protein of $>100$ amino acids are present within this DNA sequence. The first Met is immediately preceded by a consensus sequence for the initiation of protein synthesis (Fig. 3; Kozak, 1995). Analysis of the NAC-1 amino acid sequence (MacVector 4.5.3; Eastman Kodak, Rochester, NY) predicts a predominantly hydrophilic protein with three potential $\mathrm{N}$-glycosylation sites (Fig. 3). In vitro translation using the putative full-length cDNA resulted in synthesis of an $\sim 55 \mathrm{kDa}$ protein (data not shown). Comparison of the DNA and predicted amino acid sequences with those in the National Institutes of Health data base (Altschul et al., 1990) revealed areas of similarities within the $\mathrm{N}$-terminal of NAC-1 and some members of the family of zinc finger-binding proteins that regulate transcription (Fig. 4). These regions of similarity, $\sim 60 \%$ of amino acids over a stretch of 120 residues, comprise a POZ domain that is believed to mediate protein-protein interactions (Bardwell and Treisman, 1994). NAC-1 and its predicted protein sequence do not share any similarities to members of the G-protein-coupled membrane receptor family.

\section{Tissue distribution of NAC-1}

The mRNA for NAC-1 was detected in most rat tissues. However, it is expressed at higher levels in the CNS when compared with peripheral organs, and hybridization signals were barely observed in the heart and liver (Fig. 5). The probe hybridized to only one mRNA in the tissues examined, with a total size of $\sim 4400$ nt (Fig. 5). A mRNA of the same size is present in neural and non-neural tissues of the adult mouse and in the pheochromocytoma cell line PC 6-3 (data not shown). NAC-1 mRNA is present in relatively high amounts in the whole brain of the 18-d-old rat fetus (Fig. 5, E18) but was not detected in the midgestation mouse embryo (data not shown).

\section{In situ hybridization studies}

Nonradioisotopic detection showed that NAC-1 is expressed in the nucleus accumbens, olfactory tubercle, striatum, frontal and parietal cortex, ventral pallidum, and hippocampus (data from the olfactory tubercle and nucleus accumbens are illustrated in Fig. 6). Pyramidal cells in the olfactory tubercle (Fig. 6 $A$ ) and hippocampus (layers CA1, CA2, and CA 3 ) are stained by NAC-1 cRNA, suggesting that this mRNA is present in neurons. The distribution of cells expressing NAC- 1 is more patchy in other regions, such as in the nucleus accumbens (Fig. $6 C$ ) and caudateputamen. Cells in both the core and shell of the nucleus accumbens were stained by NAC-1 cRNA. The distribution of NAC-1 in the brainstem has not yet been systematically examined.

The number of cells that express NAC-1 in the nucleus accumbens increased after 3 weeks of intravenous cocaine selfadministration, followed by 3 weeks of withdrawal $(88 \pm 15$ compared with $33 \pm 9$ cells in saline-treated rats; $p<0.01$; Fig. $6 C, D)$. Similar changes in the numbers of NAC-1-positive cells after withdrawal from cocaine use were not apparent in the olfactory tubercle, ventral pallidum, and caudate-putamen in the same rats.

\section{Time course of NAC-1 expression in the nucleus accumbens after noncontingent cocaine treatment}

Northern blot analysis demonstrated that NAC-1 mRNA levels in the nucleus accumbens changed in response to intraperitoneal injections of cocaine (Table 1). Significant increases in the relative values for NAC-1 mRNA were observed at both 1 and $24 \mathrm{hr}$ after a single intraperitoneal injection of cocaine. There was also an approximate twofold increase in NAC-1 levels 1 week after chronic cocaine. However, NAC-1 levels were similar between cocaine- and saline-treated rats $6 \mathrm{hr}$ after the last daily injection.

\section{DISCUSSION}

The present experiments identified NAC-1, a novel mRNA isolated from the nucleus accumbens of the rat brain that is increased in response to cocaine self-administration, followed by a 3 week withdrawal period. Regulation of NAC-1 mRNA represents a long-lasting effect of cocaine use on gene expression that is restricted to the nucleus accumbens. It is also present 1 week after withdrawal from $6 \mathrm{~d}$ of noncontingent cocaine administration. The nucleus accumbens is a region critical to persistent changes in behavior that result from chronic cocaine use (Kalivas and Stewart, 1991; Nestler et al., 1993; F. J. White et al., 1995). This suggests that increases in NAC-1 mRNA expression may play a role in the alterations associated with the abuse of psychostimulants.

\section{NAC-1 encodes a novel protein}

Comparison of the predicted amino acid sequence for NAC-1 with the sequences for $>200,000$ known proteins (Altschul et al., 1990) reveals that this protein has not been described previously. The identified open reading frame of 514 amino acids (Fig. 3) is most likely correct for several reasons. The total length of the overlapping clones isolated from a high-stringency screen of a rat whole brain library is similar to the size of NAC-1 mRNA detected by Northern blot analysis ( $\sim 400 \mathrm{nt}$; Figs. 1, 5). The predicted initiation codon is part of a consensus sequence described in the scanning model of protein synthesis (Fig. 3; Kozak, 1995). This region in NAC-1 contains the critical residues, a purine nucleotide three bases before and a guanine nucleotide one base after the AUG codon. In addition, in vitro translation resulted in a protein of the size predicted by the open reading frame. Analysis of the predicted peptide sequence of NAC-1 suggests that it is not a membrane-spanning or secreted protein. NAC-1 has an abundance of hydrophilic amino acids without any apparent hydrophobic regions required to span a lipid bilayer. In addition, the $\mathrm{N}$ terminal does not contain a typical leader sequence necessary for membrane insertion and secretion of proteins.

NAC-1 mRNA is expressed in some neurons, as demonstrated by the intense staining seen with in situ hybridization studies in the pyramidal layers of the olfactory tubercle (Fig. 6A) and hippocampus. NAC-1 mRNA is also present in pheochromocytoma cells (X.-Y. Cha and S. A. Mackler, unpublished observations), further demonstrating its expression in neuronal cell types. The present studies have not, however, determined whether NAC-1 mRNA is also expressed in glial cells. The presence of NAC-1 in non-CNS tissues (Fig. 5) does indicate that expression of this cocaine-regulated mRNA is not exclusively restricted to neurons.

\section{NAC-1 contains a POZ domain in the $\mathbf{N}$ terminal}

The $\mathrm{N}$ terminal of the predicted NAC-1 protein contains 34 of the 37 conserved residues that are believed to comprise a POZ domain (Fig. 3; Bardwell and Treisman, 1994). This stretch of high similarity among noncontiguous amino acids strongly suggests that NAC-1 includes a functional POZ domain. The POZ domain mediates protein-protein interactions among specific 
CCGCGGCGGCCGCAGAGGCGGAGGCCGAGGCCGAGGCGCAGGUUGGCGCGCCCCGGGCCCAGGCCCGGCCCCAGCTG CCGCTGCGGAGCCCGCCGGGAGGCCCCGGAGCGCGGCCACAGCGCAGCTGCTGCC ATG GCG CAG ACC CTG 147 $\begin{array}{llllll}M & A & Q & T & L & 5\end{array}$

CAG ATG GAG ATT CCA AAC TTT GGC AAC AGC ATC CTC GAG TGC CTC AAT GAG CAG CGG 204

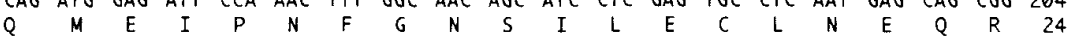

CTA CAG GGA CTG TAT TGT GAC GTG TCA GTG GTG GTA AAG GGC CAT GCC TTC AAA GCC 261 CAC CGT GCT GTG TTG GCC GCC AGC AGC TCC TAC TTC CGG GAC CTA TTC AAC AGC AGC 318

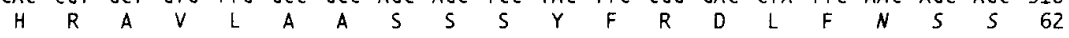
CGC AGT GCT GTG GTA GAA CTG CCA GCC GCT GTG CAG CCA CAG TCA TTC CAG CAG ATC 375 $\begin{array}{llllllllllllllllllll}R & S & A & V & V & E & L & P & A & A & V & Q & P & Q & S & F & Q & Q & I & 81\end{array}$ CTC ACG TIT TGT TAT ACA GGC CGG CTG AGC ATG AAC ATG GGG GAC CAG TTC CTG CTC 432

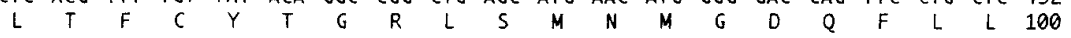
ATC TAC ACA GCC GGC TTC CTG CAG ATC CAG GAG ATC ATG GAG AAA GGC ACT GAG TTC 489 $\begin{array}{llllllllllllllllllll}I & Y & T & A & G & F & L & Q & I & Q & E & I & M & E & K & G & T & E & F & 119\end{array}$ TTC CTC AAA GTT AGC TCT CCA AGT TGC GAC TCC CAG GGC CTG CAC CCG GAG GAG GCC 546 CCA TCC TCA GAG CCT CAG AGT CCT GTA GCG CAG ATA TTG GGC TGG CCA GCC TGT AGC 603 $\begin{array}{llllllllllllllllllll}P & S & S & E & P & Q & S & P & V & A & Q & I & L & G & W & P & A & C & S & 157\end{array}$ ACG CCA CTG CCC CTT GTG TCA CGG GTC AAG ACA GAA CAG GAG TTG GAC TCG GTG CAA 660

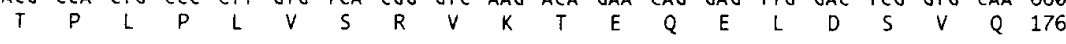
TGC ACA CCC ATG GCC AAG AGG CTA TGG GAT AGC AGC CAG AAG GAA GCT GGA GGC AGT 717 GGT GGC AAC AAT GGC AGC CGC AAG ATG GCC AAG TTC TCC ACG CCA GAC CTG GCC CCT 774

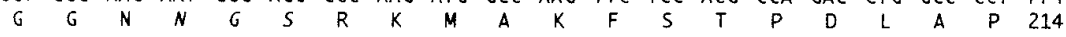

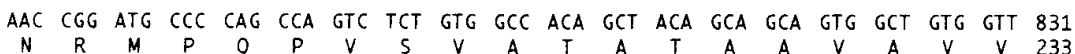
GCA GTG GGG GGA TGT GTG AGT GGG CCC AGC ATG TCA GAG CGG ACC AGC CCA GGT ACC 888

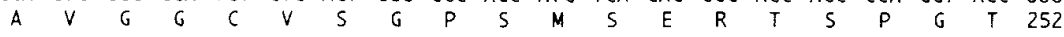

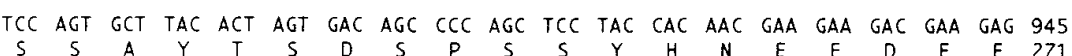
GAA GAT GCA GGT GAG GAG GGC ACA GAT GAG CAG TAC CGT CAG ATC TGC AAT ATG TAT 1002

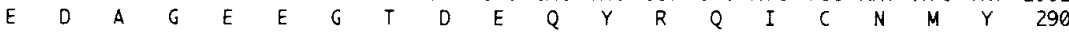

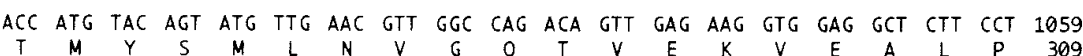
GAG CAG GTC GTC CTT GAG TCC CAC AGT CGC ATT CGA GTG CGG CAA GAC CTG GCA TCT 1116

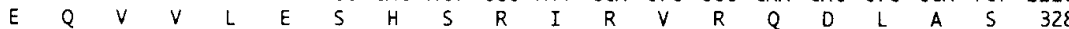
CTC CCA GCT GAG CTC ATC AAC CAG ATC GGC AAT CGC TGC CAC CCA AAÚ CTC TAC GAT 1173

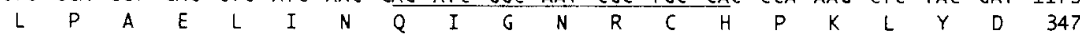
GAA GGC GAC CCC TCA GAG AAG CTG GAG CTT GTG ACA GGC ACC AAT GTA TAC ATC ACA 1230$$
\text { E }
$$
AGG GCA CAA CTC ATG AAC TGC CAC GTC AGT GCA GGC ACG CGG CAC AAG GTC TTG CTG 1287

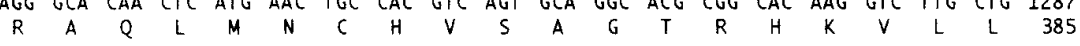
CGG CGG CTC CTG GCT TCC TTC TTT GAC CGG AAC ACA CTG GCC AAT AGC TGT GGC ACC 1344 $\begin{array}{llllllllllllllllllll}R & R & L & L & A & S & F & F & D & R & N & T & L & A & N & S & C & G & T & 404\end{array}$ GGC ATC CGT TCT TCC ACC AAT GAC CCT AGA CGC AAG CCA CTG GAC AGT CGT GTC CTC 1401 CAT GCT GTC AAG TAC TAC TGC CAG AAC TTC GCC CCC AAC TTC AAG GAG AGC GAG ATG 1458

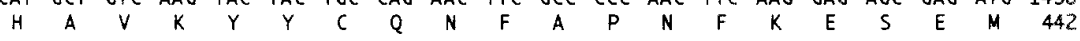

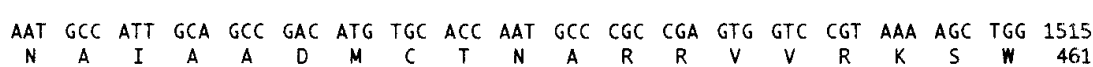
CTG CCC AAG aCC AaG CCG CTA CAC CTG GTG GAG GGC GAT AaC TAC AGC aGC TTC ATC 1572

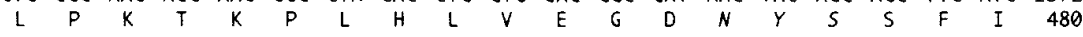
AGC GAC ACT GGC AAG ATA GAA CCG GAC ATG ATG AGC ATG GAA CAC AGC TTC GAG ACA 1629

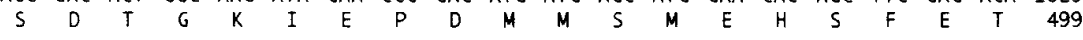
GCC AGC CAC GAT GGC GAG GCT GGC CCT TCA GCT GAG GTT CTC CAG TAA 1677 A S H D G E A G P S A E V L Q * 514 CATACATGTGACACCCCCTTACCGGATGTCACATTCCCCCTCCTATCACACCCCCACCTACCACCTACCTGGTCA 1752 CGATCTACTGTCTGTCCCTCCCCAGAACCTGT GAGGGGGTGTTCAGTGCCCTCTATCGGATGCAAGAGCTGGCTG 1827 ACCAAGGCCAAAGCACT GTACCTAGCAGAGGGCAGT GCCGACAGCAGCTTTCTCAATGACCATGAGGAAGAGCTG 1902 AACTTGGTAGGCATAGAATACAGCTTCCACACAGACAGCCCCCTCAGCAGAGGTCCTCCAGTACCTGCCCAGGAC 1977

CCTCCCATGGATGT CACACTCCCCTCCTGTCACACACATACCCCCACCTTAGTCACGAGCTACTGTG 2044

Figure 3. DNA and the predicted amino acid serounding $5^{\prime}$ and $3^{\prime}$ regions are shown. The first underinitiation of protein synthesis. The two other underlined regions indicate the locations where the PCR primers $\mathrm{SSTR}_{4}$ and TM7 hybridized in the PCR of a partial-length cDNA. Potent 60-62, 199-201, and 475-477). The predicted termination codon is noted (*); GenBank accession number AF015911. 
AQTLQMEIPNFGNSILECCLNEQRLQGUYYCDVSSTVVVKGHAFKAHRAVLAASSSSSYYRDLLFN

$L \quad L R \quad$ LCDV I V G F AHK VLA S YF LF

I QL FVILAE I GRIS F ML

F MF MSCVIN V V C V IY

$M F \quad T \quad C D$

61

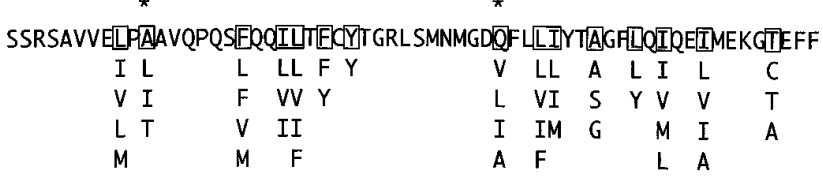

Figure 4. NAC-1 contains a POZ domain consensus sequence. The first 120 amino acids of NAC- 1 are aligned above the consensus sequence for the POZ domain from 28 different proteins (Bardwell and Treisman, 1994). The N terminal of NAC-1 matches the POZ conserved sequence in 34 of 37 residues (boxed letters); the nonmatching amino acids are indicated by asterisks. There is a conservative substitution in position 71 (Ala instead of other neutral, hydrophobic residues). The predicted structure of this $\mathrm{N}$ terminal of NAC- 1 consists of $\alpha$-helices and $\beta$-pleated sheets, a uniform characteristic observed in other POZ proteins.

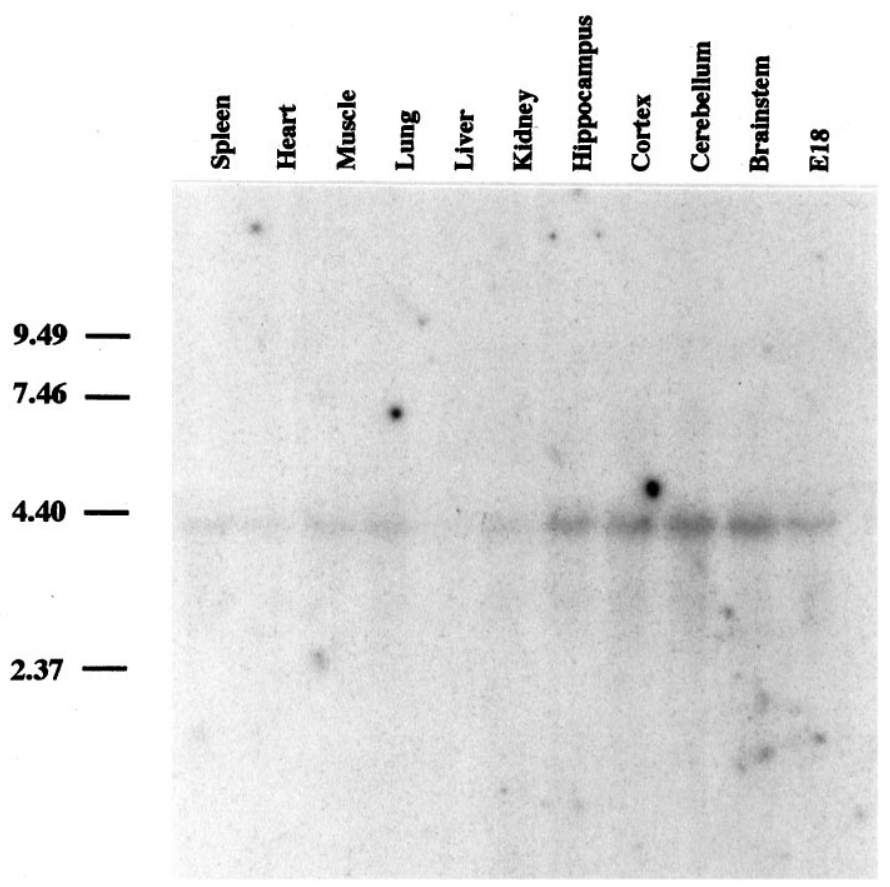

Figure 5. Tissue distribution of NAC-1 mRNA in the rat. A single mRNA species is detected in total RNA from multiple tissues. The hybridization signal is approximately three- to fourfold more intense for the four CNS regions, as compared with peripheral organs. The relative levels of NAC-1 mRNA in the nucleus accumbens and caudate-putamen are similar to those in the CNS regions shown in this figure. NAC-1 mRNA is also present in the brain from a day 18 embryo (E18). A signal is not obvious in liver mRNA. The distribution of an RNA molecular ladder is listed on the left.

members of the zinc finger family of transcriptional activators. A POZ domain is also present in some pox viruses, structurally related molecules, and other proteins (Albagli et al., 1995). This domain can form homo- or heterodimers in vitro; electrophoretic mobility assays have shown that the formation of protein dimers via a POZ domain will decrease binding to DNA consensus sequences and reduce transcription of genes downstream to the appropriate consensus sequences (Bardwell and Treisman, 1994). The predicted C-terminal region of NAC-1 does not match other known proteins, and the function of this region of the protein is not clear.

Several previous studies have shown that cocaine affects the expression of multiple transcriptional regulators in the mammalian CNS. Acute cocaine treatment (a single injection) is associated with increases in most members of the immediate early gene family in the dorsal and/or ventral striatum, including $c$-fos, $c$-jun, fos B, junB, and zif-268 (Graybiel et al., 1990; Hope et al., 1992). Increases in the expression of some immediate early genes are mediated by both $\mathrm{D}_{1}$ dopamine (Young et al., 1991) and serotonin receptors (Bhat and Baraban, 1993). Most of these altered mRNA levels return to baseline after several days of cocaine treatment or after several days without cocaine; one exception is DNA binding activity at AP-1 sites in response to an acute cocaine injection after $14 \mathrm{~d}$ of cocaine treatment (Hope et al., 1994). A majority of previous studies, however, suggest that noncontingent cocaine administration for several days does not result in persistent changes in the levels of specific mRNAs that regulate transcription. The effects of withdrawal from chronic cocaine use have not been examined in the same detail but are believed to return to baseline values. The inducibility of Fos and Jun proteins in dorsal striatal neurons after an acute cocaine challenge, for example, returned to control levels after 2 weeks of withdrawal after 1 week of cocaine, and FRA proteins were detected at similar levels after the same $14 \mathrm{~d}$ period (Moratalla et al., 1996).

\section{Increased NAC-1 mRNA levels represent a long-lasting effect of noncontingent- and self-administered cocaine}

In contrast to transient alterations in immediate early gene expression found in other studies (see above), the increase in expression of NAC- 1 mRNA was present 1 and 3 weeks after withdrawal from noncontingent- and self-administered cocaine, respectively. The fact that noncontingent and contingent cocaine administration produced long-term alterations in NAC-1 expression in the nucleus accumbens indicates that the effect is primarily a consequence of cocaine itself and is not caused by other factors that are associated with drug self-administration, such as environmental stimuli associated with injection or the learning process of pressing a lever for cocaine.

The in situ hybridization results (Fig. 6) verify a marked increase in NAC-1-expressing cells after withdrawal from cocaine self-administration, as compared with the results of the Northern blots (Fig. 2). Furthermore, the in situ data confirm that the increase in NAC-1 mRNA levels after withdrawal from cocaine is restricted to the nucleus accumbens (Fig. 2), and increased expression of NAC-1 was not significantly manifest in the dorsal striatum. The nucleus accumbens is known to be critical in the expression of both self-administration behavior and behavioral sensitization to cocaine (Roberts et al., 1977; Pettit et al., 1984; Kalivas and Stewart, 1991; Nestler et al., 1993; Self et al., 1994). Thus, the relatively specific increase in NAC-1 transcripts in the nucleus accumbens supports the hypothesis that regulated NAC-1 expression is potentially important in cocaine selfadministration and behavioral sensitization.

The time course of NAC-1 regulation by noncontingent cocaine is also informative (Table 1). A single dose of cocaine was associated with increased mRNA levels at 1 and $24 \mathrm{hr}$. If NAC-1 is involved in the regulation of gene transcription (a possible function supported by the presence of a POZ domain), then the response to cocaine lasts longer, as compared with the responses to other transcription factors (e.g., Graybiel et al., 1990; Hope et 
Figure 6. In situ hybridization studies of NAC-1 expression. $A$, Hybridization of a NAC-1 cRNA probe in the olfactory tubercle. Intense staining is seen throughout the pyramidal cell layer. $B$, Hybridization of a sense cRNA probe to a tissue section adjacent to the section shown in $A$. There is not any obvious staining of cells, demonstrating the specificity of the cRNA probe. $C$, NAC-1 mRNA expression in the nucleus accumbens of a yoked-saline control rat. An antisense probe detected NAC-1-positive cells scattered throughout the core and shell regions. $D$, NAC-1 mRNA expression in a similar region of the nucleus accumbens of a rat after withdrawal from daily cocaine selfadministration. Note the increased numbers of stained cells, as compared with those in $C$. The appearance of individual NAC-1-expressing cells is indicated by the arrowheads. The inset is a high-power view of the outlined region in $D$; the cytoplasmic location of the stain is visible. The inset also shows the presence of cells in which NAC-1 was not detected. Medial is to the left in $A-C$ and to the right in $D$. Ventral is to the bottom in all pictures. The anterior portion of the anterior commissure is indicated by an asterisk in $C$ and $D$. Scale bars: $A-D, 120 \mu \mathrm{m}$; inset in $D$, $60 \mu \mathrm{m}$.
A

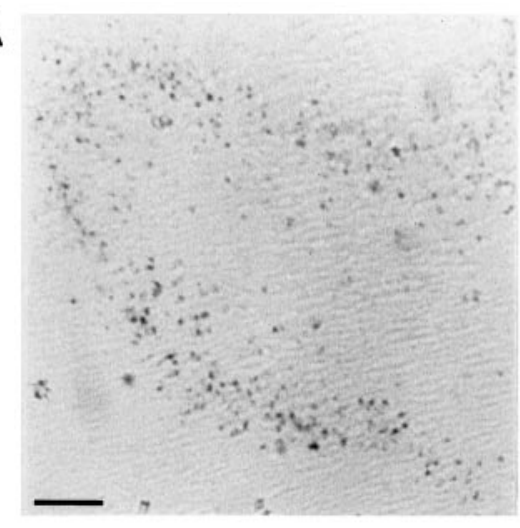

C

B

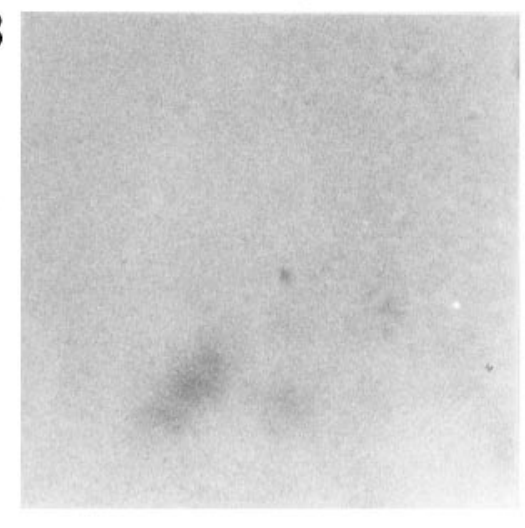

D
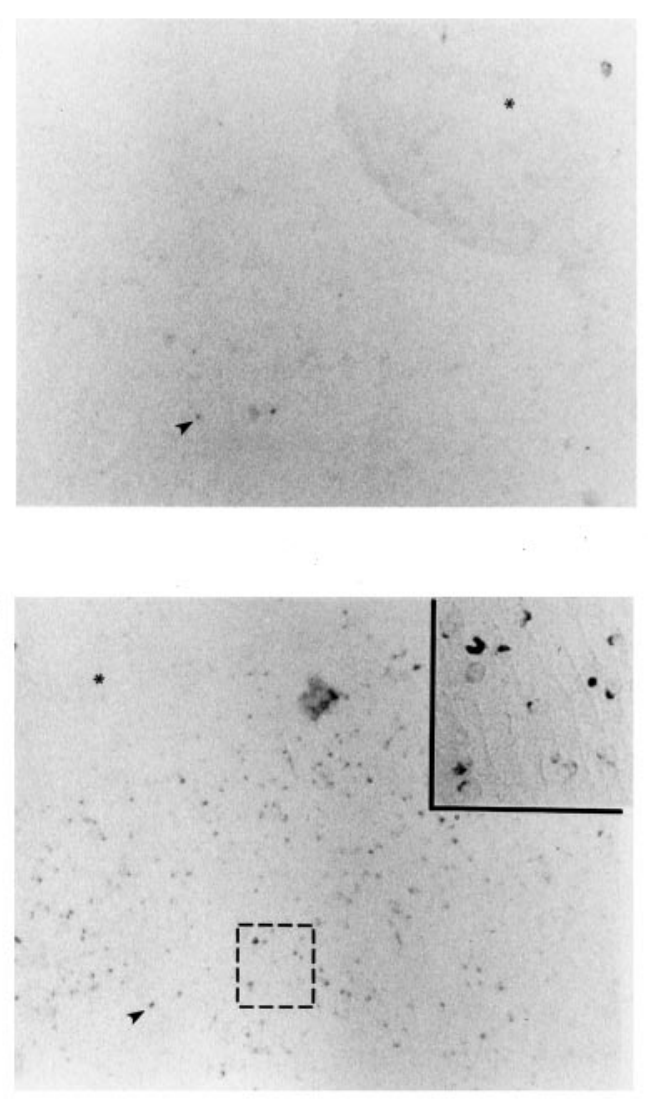

Table 1. Effects of noncontingent cocaine on NAC-1 mRNA levels in the nucleus accumbens

\begin{tabular}{lllll} 
& $\begin{array}{l}1 \mathrm{hr} \text { after } \\
\text { cocaine }\end{array}$ & $\begin{array}{l}24 \mathrm{hr} \text { after } \\
\text { cocaine }\end{array}$ & $\begin{array}{l}6 \mathrm{~d} \text { of } \\
\text { cocaine }\end{array}$ & $\begin{array}{l}1 \text { week } \\
\text { withdrawal }\end{array}$ \\
\hline$\%$ control $\pm \mathrm{SEM}$ & $156 \pm 17^{*}$ & $238 \pm 19^{*}$ & $122 \pm 23$ & $215 \pm 35^{*}$
\end{tabular}

Northern blots were performed using poly $\left(\mathrm{A}^{+}\right)$RNA isolated from the nucleus accumbens of rats that had received intraperitoneal injections of either cocaine or saline. Values were measured relative to the hybridization signal for cyclophilin to account for transfer in each blot. Each number was then calculated as a percentage of the mean value for the saline-injected group $[100 \% \pm 9-27$ (SEM)], and the results were compared using a two-tailed Student's $t$ test.

${ }^{*} p \leq 0.01$ compared with control.

al., 1992). Levels after $6 \mathrm{~d}$ of daily cocaine returned to control values (Table 1), suggesting that tolerance developed to the cocaine induction of NAC-1 expression. However, this was relatively transitory because there was a marked increase in NAC-1 expression measured 1 week after the last daily injection. Interestingly, a similar time course has been shown for a number of neurochemical and behavioral alterations associated with sensitization to psychostimulants; the expression of enhanced locomotor activity and the increase in releasability of dopamine in the nucleus accumbens are greater at 1 week or more of withdrawal, as compared with the first $24-72 \mathrm{hr}$ after the last daily psychostimulant injection (Kolta et al., 1985; Kalivas and Duffy, 1993; Wolf et al., 1993; Paulson and Robinson, 1995; Heidebreder et al., 1996). The parallel time course between the expression of behavioral sensitization and the increase in NAC-1 expression is also consistent with the hypothesis that changes in NAC-1 expression may, in part, modulate behavioral sensitization.

\section{Summary}

NAC-1 is a novel mRNA that is present both in the CNS and in non-neuronal tissues. It is present at higher levels selectively in the nucleus accumbens after 1 week or more of withdrawal from cocaine self-administration and daily noncontingent cocaine injections. The function of the protein encoded by NAC-1 in the CNS before and after cocaine use remains to be determined. Future work will examine whether the N-terminal region of NAC-1 contains a functional POZ domain. The generation of anti-NAC-1 antibodies and antisense oligonucleotide studies should help to identify the cellular location and function of NAC-1 in vitro and in the rat CNS. Importantly, experiments will be performed to see whether the NAC-1 protein (or any related gene products) is involved in the self-administration of cocaine, as suggested by the persistent increase in the expression of NAC-1 mRNA long after cocaine use.

\section{REFERENCES}

Albagli O, Dhordain P, Deweindt C, Lecocq G, Leprince D (1995) The BTB/POZ domain: a new protein-protein interaction motif common to DNA- and actin-binding proteins. Cell Growth Differ 6:1193-1198.

Altschul SF, Gisg W, Miller W, Myers EW, Lipman DJ (1990) Basic local alignment search tool. J Mol Biol 215:403-410.

Bardwell VJ, Treisman R (1994) The POZ domain: a conserved proteinprotein interaction motif. Genes Dev 8:1664-1677.

Bhat RV, Baraban JM (1993) Activation of transcription factor genes in striatum by cocaine: role of both serotonin and dopamine systems. J Pharmacol Exp Ther 267:496-505.

Daunais JB, McGinty JF (1995) Cocaine binges differentially alter striatal prodynorphin and zif/268 mRNAs. Mol Brain Res 29:201-210.

Delfs JM, Schreiber L, Kelley AE (1990) Microinjection of cocaine into the nucleus accumbens elicits locomotor activation in the rat. J Neurosci 10:303-310. 
Douglass J, McKinzie AA, Couceyro P (1995) PCR differential display identifies a rat brain mRNA that is transcriptionally regulated by cocaine and amphetamine. J Neurosci 15:2471-2481.

Feinberg P, Vogelstein B (1983) A technique for radiolabeling DNA restriction endonuclease fragments to high specific activity. Anal Biochem 132:6-13.

Graybiel AM, Moratalla R, Robertson HA (1990) Amphetamine and cocaine induce drug-specific activation of the $c$-fos gene in striasomematrix and limbic subdivisions of the striatum. Proc Natl Acad Sci USA 87:6912-6916.

Heidebreder CA, Thompson AC, Shippenberg TS (1996) Role of extracellular dopamine in the initiation and long-term expression of behavioral sensitization to cocaine. J Pharmacol Exp Ther 278:490-502.

Hooks MS, Duffy P, Striplin C, Kalivas PW (1994) Behavioral and neurochemical sensitization following cocaine self-administration. Psychopharmacology (Berl) 115:265-272.

Hope B, Kosofsky B, Hyman SE, Nestler EJ (1992) Regulation of immediate-early gene expression and AP-1 binding in the rat nucleus accumbens by chronic cocaine. Proc Natl Acad Sci USA 89:5764-5768.

Hope BT, Nye HE, Kelz MB, Self DW, Iadarola MJ, Nakabeppu Y, Duman RS, Nestler EJ (1994) Induction of long-lasting AP-1 complex composed of altered Fos-like proteins in brain by chronic cocaine and other chronic treatments. Neuron 13:1235-1244.

Hurd YL, Brown EE, Finlay JM, Fibiger HC, Gerfen CR (1992) Cocaine self-administration differentially alters mRNA expression of striatal peptides. Mol Brain Res 13:165-170.

Kalivas PW, Duffy P (1993) Time course of extracellular dopamine and behavioral sensitization to cocaine. J Neurosci 13:266-275.

Kalivas PW, Stewart J (1991) Dopamine transmission in the initiation and expression of drug- and stress-induced sensitization of motor activity. Brain Res Rev 16:223-244.

Kolta MG, Shreve P, De Souza V, Uretsky NJ (1985) Time course of the development of the enhanced behavioral and biochemical responses to amphetamine after pretreatment with amphetamine. Neuropharmacology 24:823-829.

Kozak M (1995) Adherence to the first-AUG rule when a second AUG codon follows closely upon the first. Proc Natl Acad Sci USA 92:2662-2666.

Mackler SA, Eberwine JH (1992) The molecular biology of addictive drugs. Mol Neurobiol 5:45-58.

Mackler SA, Eberwine JH (1995) Cellular adaptation to opiates alters ion-channel mRNA levels. Proc Natl Acad Sci USA 91:385-389.

Moratalla R, Elibol B, Vallejo M, Graybiel AM (1996) Network-level changes in expression of inducible Fos-Jun proteins in the striatum during chronic cocaine treatment and withdrawal. Neuron 17:147-156.

Muhlegger K, Batz HG, Bohm S, Eltz HVD, Holtke HJ, Kessler C (1989) Synthesis and use of new digoxigenin-labelled nucleotides in non-radioactive labeling and detection of nucleic acids. Nucleosides Nucleotides 8:1161-1163.

Nestler EJ (1992) Molecular mechanisms of drug addiction. J Neurosci $12: 2439-2450$.
Nestler EJ, Hope BT, Widnell KL (1993) Drug addiction: a model for the molecular basis of neural plasticity. Neuron 11:995-1006.

Paulson PE, Robinson TE (1995) Amphetamine-induced timedependent sensitization of dopamine neurotransmission in the dorsal and ventral striatum: a microdialysis study in behaving rats. Synapse 19:56-65.

Pettit HO, Ettenberg A, Bloom FE, Koob GF (1984) Destruction of dopamine in the nucleus accumbens selectively attenuates cocaine but not heroin self-administration in rats. Psychopharmacology (Berl) 84:167-173.

Raynor K, O'Carroll AM, Kong H, Yasuda K, Mahan LC, Bell GI (1993a) Characterization of cloned somatostatin receptors $\mathrm{SSTR}_{4}$ and SSTR $_{5}$. Mol Pharmacol 44:385-392.

Raynor K, Lucki I, Reisine T (1993b) Somatostatin 1 receptors in the nucleus accumbens selectively mediate the stimulatory effect of somatostatin on locomotor activity in rats. J Pharmacol Exp Ther 265:67-73.

Roberts DCS, Corcoran ME, Fibiger HC (1977) On the role of the ascending noradrenergic systems in intravenous self-administration of cocaine. Pharmacol Biochem Behav 6:615-620.

Robinson TE, Becker JB (1986) Enduring changes in brain and behavior produced by chronic amphetamine administration: a review and evaluation of animal models of amphetamine psychosis. Brain Res Rev 11:157-198.

Sanger F, Nicklen S, Coulson AR (1977) DNA sequencing with chainterminating inhibitors. Proc Natl Acad Sci USA 74:5463-5467.

Self DW, Terwilliger RZ, Nestler EJ, Stein L (1994) Inactivation of $G_{i}$ and $G_{o}$ proteins in the nucleus accumbens reduces both cocaine and heroin reinforcement. J Neurosci 14:6239-6247.

Short JM, Fernandez JM, Sorge JA, Huse WD (1988) $\lambda$ ZAP: a bacteriophage $\lambda$ expression vector with in vivo excision properties. Nucleic Acids Res 16:7583-7600.

Tecott LH, Barchas JD, Eberwine JH (1988) In situ transcription: specific synthesis of complementary DNA in fixed tissue sections. Science 240:1661-1664.

White FJ, Xiu Y-H, Henry DJ, Zhang X-F (1995) Neurophysiological alterations in the mesocorticolimbic dopamine system during repeated cocaine administration. In: The neurobiology of cocaine addiction (Hammer R, ed), pp 99-120. Boca Raton, FL: CRC.

White SR, Harris GC, Imel KM, Wheaton MJ (1995) Inhibitory effects of dopamine and methylenedioxymethamphetamine (MDMA) on glutamate evoked firing of nucleus accumbens and caudate/putamen cells are enhanced following cocaine self-administration. Brain Res 681:167-176.

Wolf ME, White FJ, Nassar R, Brooderson RJ, Khansa MR (1993) Differential development of autoreceptor subsensitivity and enhanced dopamine release during amphetamine sensitization. J Pharmacol Exp Ther 264:249-255.

Young ST, Porrino LJ, Iadarola MJ (1991) Cocaine induces striatal c-Fos-immunoreactive proteins via dopaminergic $\mathrm{D}_{1}$ receptors. Proc Natl Acad Sci USA 88:1291-1295. 